Ambient Science, 2016: Vol. 03(Sp2); 01-04 DOI:10.21276/ambi.2016.03.sp2.ga01

\title{
The Effects of Water Crisis on Food Production in Iran
}

\section{Jamil Zargan', Seyed Mohammad Waez- Mousavi $^{2 *}$ \\ ${ }^{1}$ Center for Biological Science and Technology, Faculty of Basic Sciences, Imam Hossein University, Tehran, Iran. \\ ${ }^{2}$ Gorgan University of Agricultural Sciences and Natural resources, Gorgan, Iran.}

Key words: Groundwater, Water scarcity

\section{Abstract}

Food is an essential factor to human life and its production is strongly related to water. Regions without enough available water are subjected to food security threat. Iran is a country in the water-scarce region of the Middle East and a great part of it is arid and semi-arid areas. This study aimed to investigate the effect of water crisis on food production of Iran. Results showed that Iran is suffering from a high water stress situation. The agriculture sector of Iran is the major source for feeding its fast growing population and this section has put a severe pressure on groundwater resources in order to meet food demand of the country. Since then Iran has used a great part of its hydrologic renewable water resources and due to which it could be estimated that the withdrawals reached to non-renewable part of groundwater. Thus, Iran's agriculture would face a great challenge of water shortage in near future and the food security of the country will be threatened. Using new irrigation methods and technology and revision of crop pattern in agriculture are suggested in order to confront the threat of water crisis to the food security of Iran.

threat.The Middle East is the largest part of the world with water shortage (Khodarahimi \& Deghani, 2012; RoudiFahimi et al., 2002) and one of the regions of the world which are facing a serious water crisis (Gürsoy \& Jacques, 2014; Zyadin, 2013). Despite having 14\% of world's area and $6 \%$ of its population, the Middle East enjoys only $1.4 \%$ of world's renewable freshwater resources (Al-Rimmawi, 2012). The region is suffering an imbalance between water availability and its demand and this imbalance is becoming deeper over time (Zyadin, 2013). Since the water is a "scarce" factor in the Middle East, therefore the region has a history of water-based political conflicts (Gürsoy \& Jacques, 2014).

Iran,as a Middle Eastern country,receives only about $250 \mathrm{~mm}$ of annual precipitation on the average, about onethird of the global average (Motiee et al., 2012), yet about two third of this low precipitation is being vanished because of evaporation (Lehane, 2014). About $65 \%$ of the country is considered as arid and the $20 \%$ is semi-arid (Madani, 2014). Also, the water resources distribution in the country and temporal distribution of precipitation during the year is heterogeneous and uneven (Nabizadeh enough available water are subjected to food security

*Corresponding Author: waezmousavi@gau.ac.ir 
Zolpirani et al., 2015; Khodarahimi \& Deghani, 2012). Water scarcity in Iran is incorporated with inefficient water use where the domestic use of water is $70 \%$ more than the world's average (Lehane, 2014).

Water shortage in Iran has been considered as one of the limiting factors for sustainable development (Nabizadeh Zolpirani et al., 2015) and it is predicted that Iran is among the countries which will face an absolute water scarcity until 2025 (Seckler et al., 1998).

Regarding the crucial role of water in food security, this study aims to investigate the water crisis condition in Iran and its effect on food security of the country.

\section{Grounded Theory Method:}

This method was defined as: "a general methodology of analysis linked with data collection that uses a systematically applied set of methods to generate an inductive theory about a substantive area" (Glaser, 1992). Therefore, a big number of resources including research articles, books, theses, technical reports and national as well as international databanks, in both English and Persian (Iran's national language), were studied in order to assess Iran's water crisis condition. Then the effect of water crisis on food security of the country was studied and predicted.

\section{Available scenario:}

Based on World Bank (2016), Iran's renewable water resources per capita is 1644 ( $\mathrm{m}_{3} /$ inhab/year) which is less than 1700 (m3/inhab/year), the minimum threshold proposed by Falkenmark (1989). According to Falkenmark (1989) countries with renewable water of less than 1700 (m3/inhab/yr) are in "water stress" condition. The per capita renewable water of Iran was 2000 (m3/inhab/year) in 2005 and 1799 in 2014 (FAO AQUASTAT, 2016). Even the per capita renewable water of Iran is estimated to decrease to about 1530 by 2025 (Mokhtari-Hashi, 2013). This dramatic decline in per capita renewable water is mostly due to population growth in the one hand and reduction in renewable water resources of the country on the other hand. While Iran's total population increased from 56.4 million in 1990 to 78.5 million in 2014, but its rural population decreased from 24.6 million in 1990 to 23.9 million in 2014 (FAO, 2015) (Table 1). In addition, a total annual water withdrawal of Iran is about $70 \%$ of its renewable water resources (Madani, 2014), while any country with withdrawals more than $40 \%$ of its available water resources could be considered under "severely water scarce" (Raskin et al., 1997). Many types of research have been reviewed in order to find the principle causes of the water shortage in Iran. Madani (2014) introduced three main causes for water crisis of Iran including: “(1) rapid population growth and inappropriate spatial population distribution; (2) inefficient agriculture sector; and (3) mismanagement and thirst for development". He emphasizes on mismanagement as the main reason for this crisis. Mismanagement of water resources has Also been referred to as one of the main causes of Iran's water crisis by many other researchers (Nabizadeh Zolpirani, 2015; Jani \& Yazdanian, 2014; Madani, 2014, Lehane, 2014; Javan \& FalSoleiman, 2008; Babran \& Honarbakhsh 2008). Also inefficient agriculture (Madani, 2014; Jani \& Yazdanian, 2014; Jajarmi et al., 2013; Taheri \& Alizadeh, 2011; Mousavi et al., 2010; Javan \& FalSoleiman, 2008), water pollution (Jani \& Yazdanian, 2014; Jajarmi et al., 2013; Babran \& Honarbakhsh, 2008; Rahimi, 2003), groundwater over-withdrawal (Shahedi \& Talebi Hossein Abad, 2014; Rahnema \& Mirassi, 2014; Jani \& Yazdanian, 2014) and climate change (Rahnema \& Mirassi, 2014; Fatemi \& Karami, 2011; Faramarzi et al., 2010) have been referred to as main reasons of Iran's water crisis.

About 18 million ha of total Iran's area are being cultivated (FAO AQUASTAT, 2016), half of which is allocated to wheat production (Ahmadvand \& Najafpoor, 2010). Traditionally wheat is the backbone of Iranian food diet (Maddah et al., 2015) and therefore plays a key role in food security of the country. But only about $40 \%$ of wheat cultivation is rainfed (Bahrami et al., 2011). Thus, the wheat production of the country has a great dependency on annual precipitation which causes a significant fluctuation in wheat production occurs from year to year. Fluctuation in Iran's annual wheat and rice production, as the two main food sources of the country, during 1990-2013 is shown in Figure 1.

Table 1: Decline in rural population of Iran since 1990

\begin{tabular}{|llll|}
\hline Year & 1990 & 2000 & 2014 \\
\hline Total & 56.4 & 65.9 & 78.5 \\
Urban & 31.8 & 42.2 & 54.6 \\
Rural & $\mathbf{2 4 . 6}$ & 23.7 & 23.9 \\
\hline
\end{tabular}

\section{Effect of water crisis on food production:}

Agriculture requires 7o percent of freshwater, withdrawals at global scale (World Bank, 2016) and among all economy sectors, the agricultural sector is the most vulnerable to water scarcity (FAO, 2012). In Iran also, the vast majority of renewable water is being used in agriculture (Madani, 2014; Motiee et al., 2012).

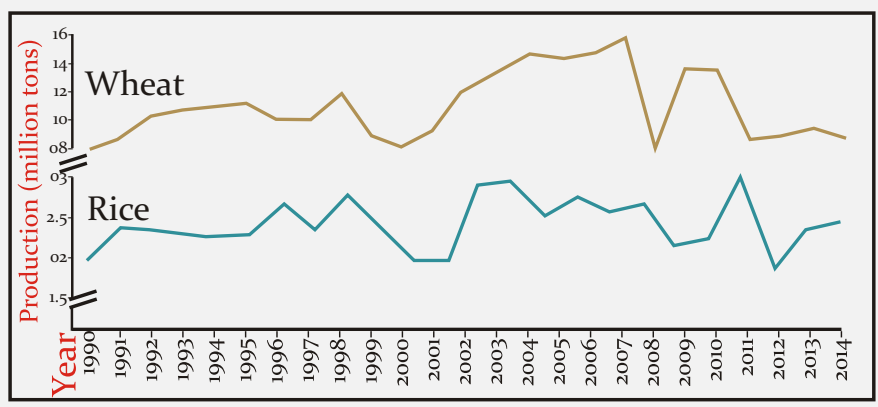

Figure -1: Iran's annual wheat and rice production (based on FAOSTAT) 
Regarding the crucial role of water in agriculture, water shortage is the main obstacle for global food security (Kumar, 2003). The situation is more worrying in the regions such as the Middle East where it is predicted that by 2025 the average per capita of renewable water will be about $500\left(\mathrm{~m}_{3} / \mathrm{inhab} / \mathrm{yr}\right)$ while the global average is about 7000 (Shetty, 2006).

The agriculture sector in Iran provides $23 \%$ of jobs and 13\% of GDP (Madani, 2014). This sector is sensitive to water shortage, as an example, the agriculture sector was intensively damaged by severe drought during 1999-2001 which caused a dramatic decline in agricultural production of the country (FAO, 2007). The effect of water shortage on agriculture in Iran is mostly reflected as the reduction of cultivable areas and the decrease of crop production per unit area. Despite the limited water resources in Iran, the agriculture sectors also suffer from water inefficiency, sometimes as low as only $35 \%$, which is mainly due to cheap water price and the government subsidy (Madani, 2014).

Changes in annual rainfall are not the only waterrelated challenge for agriculture and food production of the country, over-withdrawals of ground water and its consequence groundwater table drop is another waterrelated issue in addition. Since the annual precipitation is slight and its temporal distribution pattern through the year is uneven therefore in order to meet food demand of a growing population a severe pressure was put on groundwater resources of the country so that more than $60 \%$ of water used for irrigation was of groundwater (FAO AQUASTAT, 2016). Since then Iran became one of the biggest "groundwater miners" of the world (Madani, 2014; Gleeson et al., 2012), and due to such over-withdrawal most of the groundwater stock of the country has been consumed and about $45 \%$ of the country's plans faced a tragic drop of groundwater level (Madani, 2014). As a result of continuing drop in the groundwater table, the phenomenon of "land subsidence" happened across the country (Hosseini \& Bayat, 2014; Lashkaripour et al., 2014). Land subsidence damages water infrastructures such as water storage and conveyance systems and hence will negatively affect agriculture and food production. For example, in a research in the city of Mashhad at north-east of the country, it has been revealed that land subsidence is responsible for $52 \%$ of well devastations in the study area (Maddah et al., 2013).

Migration due to water scarcity is another challenge for food production of Iran. Migration is both a consequence and an inducer of water shortage. Migration is a common alternative to people whose life has been affected by environmental changes (Barnett \& Adger, 2007). This migration negatively affected rural areas which are "the most important economic and demographic component" of each country (Semenova et al., 2016), particularly in Iran where about $80 \%$ of basic resources for food production, namely land and water, are located in rural areas (Esmaeilifar, 2013). Migration causes population decline in rural areas where the most suitable lands for agriculture and herding are available therefore the amount of producer population of the country will decrease while urban population, the consumer population indeed, will increase. In this way, the economy of the country and food production chain will be affected. Since agriculture consumes the most amount of renewable water in Iran, any disturbance in the water supply of the country will affect the agriculture section and consequently will threat food production.

Conclusively, Iran is a country with limited water resources which currently is under water stress mode. The agriculture sector consumes the vast majority of the country's renewable water resources. Nevertheless, it is estimated that Iran withdrawals even reached to nonrenewable part of groundwater. In this way Iran's agriculture will face the challenge of water shortage in future and the food security of the country will be affected. In order to confront this challenge, a reconsideration of water management and increasing of water efficiency in agriculture is essential. Pricing of water based on its real value, increasing agricultural production through an increase in efficiency of land instead of an increase in water consumption, reforming the water storage and conveyance structures, using new irrigation methods and technology and revision in crop pattern of agriculture are examples of such reconsiderations. Also, supportive measures must be executed by the government and policy makers to encourage rural population to stay in rural areas rather than to migrate to urban areas.

\section{References:}

Ahmadvand, M.R. \& Najafpoor, Z. (2010): Investigation on cultivated area, production and supportive policies of wheat during 1 st to 4 th development plans. Q. Econ. Res. Policy., 18 (53): 59-76.

Al-Rimmawi, H. (2012): Middle East chronic water problems: solution prospects. Energy Environ. Res., 2 (1): 28-34.

Hosseini, A.M. \& Bayat, H. (2014): Monitoring land subsidence of Mashhad valley of Iran using Leveling, GPS Survey and In SAR techniques. L. Civil Eng. Urban., 4 (6):562-567.

Babran, S. \& Honarbakhsh, N. (2008): Water situation crisis in the world and Iran. Rahbord J., 16 (48):193-212.

Bahrami, H., Taki, M. \& Monjezi, N. (2011): Optimization of energy consumption for wheat production in Iran using data envelopment analysis (DEA) technique. Afr.J.Agric.Res., 6(27):5978-5986.

Barnett, J. \& Adger, N.W. (2007): Climate change, human security and violent conflict. Polit. Geography., 26: 639-655.

Esmaeilifar, A. (2013): The Role of Food Security in National Security of Islamic Republic of Iran. In: Proc. of International E-Conference on Economy under Sanctions, Iran. 
Falkenmark, M. (1989): The massive water scarcity threatening Africa: why isn't it being addressed? Ambio. 18 (2):112-118.

FAO. (1996): World Food Summit: Rome Declaration and Plan of Action.

FAO. (2007): Selected indicators of food and agricultural development in the Asia-Pacific region 1996-20o6. Food and agriculture organization of the United Nations regional off ice for Asia and the Pacif ic, Bangkok.

FAO. (2012): Coping with water scarcity, an action framework for agriculture and food security. Food and Agriculture Organization of the United Nations, Rome.

FAO. (2015): FAO Statistical Pocketbook. Food and Agriculture Organization of the United Nations.

FAO (2016). FAOSTAT database collections. Food and Agriculture Organization of the United Nations. Rome.

FAO. (2016): AQUASTAT Main Database, Food and Agriculture Organization of the United Nations (FAO).

Faramarzi, M., Yang, H., Mousavi, J., Schulin, R., Binder, C.R. \& Abbaspour, K.C. (2010): Analysis of intra-country virtual water trade strategy to alleviate water scarcity in Iran. Hydrol.Earth Syst. Sci., 14:1417-1433.

Fatemi, M. \& Karami, E. (2011): The impacts and causes of drought: A case study. Iran. Agric. Ext. Educ. J., 6 (2):77-96.

Glaser, B. (1992): Basics of Grounded Theory Analysis: Emergence v Forcing. Publisher: Sociology Press, Mill Valley, CA.

Gleeson, T., Wada, Y., Bierkens, M.F.P. \& van-Beek, L.P.H. (2012): Water balance of global aquifers revealed by groundwater footprint. Nature., 488:197200

Gürsoy, S.I. \& Jacques, P.J. (2014): Water security in the Middle East and North African region. J. Environ. Stud. Sci., 4 (4):310-314.

Jajarmi, K., Pishgamifard, Z. \& Mahkooi, H. (2013): Investigation on environmental threats in Iran's national security. $\underline{\text { Rahbord }}$ L.,22 (67): 193-230.

Javan, J. \& FalSoleiman, M. (2008): Water crisis and need for attention to efficiency of agricultural water at arid areas, case study: Birjand plain. Geogr.Dev. Iran. J., 11: 115-138.

Khodarahimi, S. \& Deghani, H. (2012): Hopefulness, positive and negative emotions in rural residents with drink water shortage: an Iranian case study. Prob. Psychol. 21st Century.,3: 32-41.

Kumar, M.D. (2003): Food security and sustainable agriculture in India: The water management challenge. Publisher: International Water Management Institute, Colombo, Sri Lanka.

Lashkaripour, Gh.R., Ghafoori, M. \& Mousavi Maddah, M. (2014): An investigation on the mechanism of land subsidence in the northwest of Mashhad city, NE Iran. J.Biodivers.Environ. Sci., 5 (3):321-327.

Lehane, S. (2014): The Iranian Water Crisis. Strategic Analysis Paper. Publisher: Future Directions international.

Madani, K. (2014): Water management in Iran: what is causing the looming crisis? L. Environ. Stud. Sci., 4 (4):315-328.

Maddah, V., Soltani, A., Zeinali, E. \& Bannayan-Aval, M. (2015): Simulating climate change impacts on wheat production in Gorgan, Iran. Bull. Environ. Pharmacol. Life Sci., 4 (4): 58-67.

Jani, M.I. \& Yazdanian, N. (2014): The analysis of water crisis conjecture in Iran and the exigent measures for its management. Ravand Q., 21 (65-66): 117-144.

Mokhtari-Hashi, H. (2013): Hydropolitics of Iran; the geography of water crisis in the horizon of 2025. Int. Q. Geopolitics., 9 (3): 49-83.

Motiee, H., Salamat, A. \& Mc Bean, E.E. (2012): Drought as a water related disaster; a case study of Oroomieh Lake. Aqua-LAC., 4 (2):7-18.

Mousavi Maddah, S.M., Ghafoori, M., Lashkaripour, Gh. \& Afshar, A. (2013): An investigation on land subsidence and its effect on rupture of water well casings in Mashhad City area. $Q$. Irrig. Water Eng., 4(13): 56-66.

Mousavi, S.N., Akbari, S.M.R., Soltani Gh. \& Zare Mehrjardi, M. (2010): Virtual water; a new solution to confront water crisis.In: Proc. of the National Conference on Water Crisis Management.

Nabizadeh Zolpirani, M., Amirnejad, H. \& Shahnazari, A. (2015): Calculating the economic value of water in paddy farms in the area of Alborz Dam. L. Novel Appl. Sci., 4 (2):197-201.

Rahimi H. (2003): Water crisis: An unknown global challenge. Peyk Noor., 1(2):24-33.

Rahnema, H. \& Mirassi, S. (2014): Drought and Water Crisis in Plains of Iran: A Case Study of Marvdasht and Khanmirza Plains, Fars and Chaharmahal and Bakhtiari Province, Iran. Int. Bull. Water Resour. Dev., 2 (1): 139-154.

Raskin, P., Gleick, P., Kirshen, P., Pontius, G. \& Strzepek, K. (1997): Water Futures: assessment of long-range patterns and prospects. Stockholm Environment Institute: Stockholm, Sweden.

Roudi-Fahimi, F., Creel, L. \& De Souza, R.M. (2002): Finding the balance: population and water scarcity in the Middle East and North Africa. Publisher: Population Reference Bureau, MENA Policy Brief: Washington.

Seckler, D., Amarasinghe, U., Molden, D., De Silva, R. \& Barker, R. (1998): World water demand and supply, 1990 to 2025 : Scenarios and issues. Research Report 19. Publisher: International Water Management Institute, Colombo, Sri Lanka.

Semenova, N.N., Busalova, S.G., Eremina, O.I., Makeikina, S.M. \& Ivanova, I.A. (2016): Assessment of sustainable development of rural areas of Russia.Indian J. Sci. Technol., 9(14):1-6.

Shahedi, M. \& Talebi Hossein Abad, F. (2014): Introducing some indices to evaluate the balance of water resources and sustainable development, Case study: Qareh-Qum basin in Iran. J. Water Sustainable Dev., 1 (1):73-39. (In Persian)

Shetty, Sh. (2006): Water, food security and agricultural policy in the Middle East and North Africa region. Working Paper Series No. 47, theWorld Bank.

Taheri, S.D. \& Alizadeh, K. (2011): Water in crisis: paths to sustainablewater use. EBNESINA-J.Med., 14 (1 \& 2): 55-6o.

World Bank. (2007): Making the most of scarcity accountability for better water management results in the Middle East and North Africa. MENA development report: Washington DC.

World Bank. (2016): World Development Indicators 2016. Washington, DC: World Bank.

Zyadin, A. (2013): Water shortage in MENA region: an interdisciplinary overview and a suite of practical solutions. J. Water Resour.Prot., 5:49-58. 